\title{
Energy Auditing and Carbon Footprint with Diverse Organic and Inorganic Fertilizer Management Options in Cereal based Cropping Systems under Conservation Agriculture: A Review
}

\author{
M. Sharath Chandra ${ }^{1 *}$, R. K. Naresh ${ }^{1}$, Vivek ${ }^{1}$, Pradeep Kumar Singh ${ }^{1}$, \\ Jana Harish $^{2}$, Pebbeti Chandana ${ }^{3}$ and K. Shivashankar ${ }^{4}$
}

\author{
${ }^{1}$ Department of Agronomy, Sardar Vallabhbhai Patel University of Agriculture \& Technology, \\ Meerut, (U.P.), India \\ ${ }^{2}$ ICAR- Indian Institute of Rice Research, Hyderabad, Telangana, India \\ ${ }^{3}$ Department of Agronomy, Tamil Nadu Agricultural University, \\ Coimbatore, Tamil Nadu, India \\ ${ }^{4}$ Department of Agronomy, University of Agricultural Sciences, Dharwad, Karnataka, India
}

*Corresponding author

\section{A B S T R A C T}

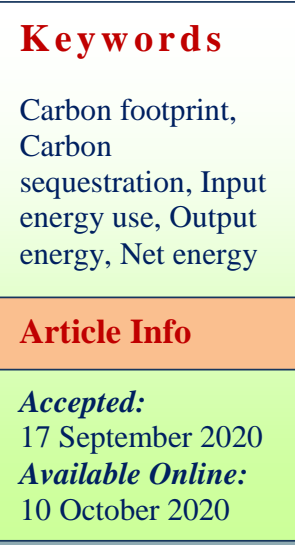

\section{Keywords}

Carbon footprint, Carbon sequestration, Input energy use, Output

\section{Article Info}

Accepted: Available Online: 10 October 2020
Soil is a key compartment for climate regulation as a source of greenhouse gases (GHGs) emissions and as a sink of carbon. Thus, soil carbon sequestration strategies should be considered alongside reduction strategies for other greenhouse gas emissions. Practicing conservation tillage, residue retention and diverse organic and inorganic fertilizer management options were advocated because of their multiple benefits. Hence we explored the energy requirement and carbon footprint of conservation agriculture (CA) based maize production systems. ZT and PB plots consumed lower energy in land preparation (49.7-51.5\%) and irrigation (16.8-22.9\%) compared to CT. Significantly higher system output (10.6-14.5\%) and net energy (14.8-18.9\%) returns, biomass productivity (9.9-14.1\%), energy use-efficiency (13.4-17.1\%), and bioenergetic based adult equivalent yield (17.3-19.8\%) was recorded in ZT and PB than the CT. Among the crop rotation plots the pooled net energy-output $\left(35,3346 \mathrm{MJ} \mathrm{ha}^{-1}\right)$, biomass yield $\left(11.87 \mathrm{Mg} \mathrm{ha}^{-1}\right)$, energy use efficiency (4.16), and bio-energetic based adult equivalent yield (46 adults ha ${ }^{-1}$ year $^{-1}$ ) was recorded significantly higher in MWMb plots. The carbon footprint for durum wheat grown after a pulse was 0.25 $\mathrm{kg} \mathrm{CO} 2 \mathrm{e}$ per kg of the grain and $0.28 \mathrm{~kg} \mathrm{CO}_{2} \mathrm{e}$ per kg of the grain when grown after an oilseed: a reduction in the carbon footprint of $24 \%$ to $32 \%$ than when grown after a cereal. The application of chemical fertilizer + FYM at 6 t/ha to rice-wheat system produced significantly higher yield attributes, economic yield, energy output of the system and higher carbon efficiency CE and net return over control and sole application of FYM at $6 \mathrm{t} / \mathrm{ha}$. The application of INM with ridge furrow sowing increased available $\mathrm{N}$ and $\mathrm{P}$ contents in the soil. The adoption of NT-RR significantly reduced the energy use $(16,727 \mathrm{MJ} / \mathrm{ha})$ compared with those under CT-RI $(27,630 \mathrm{MJ} / \mathrm{ha}$. Thus, NT-RR also increased the energy use efficiency (EUE), energy productivity (EP), and reduced carbon footprint (CF) of the system compared with those under CT-RI. Use of different mulches also increased the energy use efficiency and system productivity compared with those under NM. The total $\mathrm{CO}_{2}$-e emission (CF) was higher under CT-RI (2307 $\mathrm{kg} \mathrm{CO}_{2-}$ e/ha) as compared to those under NT-RR (2013 $\mathrm{kg} \mathrm{CO}_{2}$-e/ha). The savings of fossil fuel from less number of tillage operations and also low emissions associated with energy consumed in manufacture, transport, repair and use of machines contributed to the lowest GWP under NT-RR. Thus, the study supports and recommended that the NT-RR with BM is an environmentally safe and clean production technology for enhancing the energy use efficiency, reducing the $\mathrm{CF}$ and cost of production of direct-seeded upland rice based cropping system in India and similar agro-eco-regions elsewhere in the rice based cropping system in the world. 


\section{Introduction}

Soil is involved in the biogeochemical cycles of carbon $(\mathrm{C})$ and nitrogen $(\mathrm{N})$, and thus is a key compartment for climate regulation either by emitting greenhouse gases (GHGs) or by sequestering $\mathrm{C}$ (Fig.1). Soil stores vast amounts of $\mathrm{C}$ : the first meters of mineral soils contain between 1,500 and $2,400 \mathrm{Pg}$ of organic C (Ciais et al., 2013; Stockmann et al., 2013). This is about three to four times the amount of $\mathrm{C}$ in vegetation $(450-650 \mathrm{PgC})$ and twice to three times the amount in the atmosphere ( $829 \mathrm{GtC})$. Moreover, peat soils and permafrost account for more than 1,500 $\mathrm{Pg}$ of $\mathrm{C}$. Concerning emissions; $\mathrm{CO}_{2}$ is released from soils due to biological decay of plant litter and soil organic matter (Smith, 2004). Together with the respiration of vegetation it represents a flux of $118.7 \mathrm{PgC} \mathrm{a}$ year, which is less than the photosynthesis

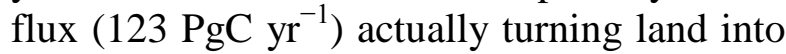
a sink. Methane $\left(\mathrm{CH}_{4}\right)$ is produced when organic materials decompose in oxygendepleted conditions, such as in rice paddies or under flooded conditions (Mosier et al., 1998). Rice cultivation is responsible for 24 $30 \mathrm{Pg} \mathrm{C}$ a year that is nearly half of the emissions originating from livestock. Nitrous oxide $\left(\mathrm{N}_{2} \mathrm{O}\right)$ is part of the global $\mathrm{N}$ cycle and is linked with other forms of $\mathrm{N}$ (e.g., organic, ammonia, nitrate). In soil, $\mathrm{N}_{2} \mathrm{O}$ is generated by the microbial transformation of organic and mineral $\mathrm{N}$, and is often enhanced under wet conditions (Oenema et al., 2005). Emissions from soil, linked to cultivation are estimated between 1.7 and $4.8 \mathrm{Tg} \mathrm{N}_{2} \mathrm{O}$ a year and are the main anthropic source.

Emissions in agriculture also include those from the inputs of fertilizers, manures, plant litter, and those from the interwoven flows of $\mathrm{N}$ among several pools. Farming also removes $\mathrm{CH}_{4}$ from the ecosystem by the oxidative activity of soil microbes, but such removals are small compared with emissions (Janzen et al., 2006). In general, carbon footprint stands for a certain amount of gaseous emissions that are relevant to climate change and associated with human production or consumption activities. With regards to crop production and other agricultural services, a larger portion of the total GHG emission occurs as $\mathrm{N}_{2} \mathrm{O}$, rather than $\mathrm{CO}_{2}$ (Janzen et al., 2006). Therefore, in our discussion, the carbon footprint relevant to agricultural products and processes is defined as the total amount of greenhouse gas emission associated with a food product or a service, expressed in carbon dioxide equivalence $\left(\mathrm{CO}_{2} \mathrm{e}\right)$. The focus is on two components: (1) the total emission per unit area per year expressed as kilograms $\mathrm{CO}_{2} \mathrm{e}$ per hectare per year, and (2) the emission per unit (kilograms) of product produced expressed as kilograms $\mathrm{CO}_{2} \mathrm{e}$ per kilogram of product. These two components parallel the approaches with which the efficiency of agricultural productivity is evaluated, i.e., (1) the net production per unit area such as grain yield per hectare per year and (2) the costs associated with the production of a unit of product such as input costs per kilograms of grain produced.

Most consumers and citizens are willing to pay for measures leading to drastic reductions in GHG emissions. A growing number of consumers want to know the carbon footprint of the food products they buy in grocery stores. In response, some multinational food companies have proposed that suppliers identify on product labels the $\mathrm{CO}_{2} \mathrm{e}$ emissions released in the production of that particular food item. Farmers are eager to adopt improved mitigation practices on their farms. Therefore, it is critical that integrated strategies and practices are developed for farming systems so as to maximize agriculture's productivity while minimizing the greenhouse gas emissions in the production of grains, fibers, feedstock's, and other agricultural products. Energy is one of 
the most valuable inputs in production agriculture. It is invested in various forms such as mechanical (farm machines, human labour, animal draft), chemical fertilizer, pesticides, herbicides), electrical, etc. The amount of energy used in agricultural production, processing and distribution should be significantly high in order to feed the expanding population and to meet other social and economic goals. Sufficient availability of the right energy and its effective and efficient use are prerequisites for improved agricultural production. It was realized that crop yields and food supplies are directly linked to energy (Stout, 1990). Bridges and Smith (1979) developed a method for determining the total energy input for agricultural practices. Lal et al., (2003), in their study on energy use and output assessment of food-forage production systems, reported sorghum (single cut) berseem + mustard - maize + cowpea as most energy efficient and remunerative system among the five forage systems. The cropping systems were evaluated in terms of energy use, biomass production and gross income etc. The benefit-to-cost (B: C) ratio for the most energy efficient forage production was $1.37: 1$. The fertility of the soil could also be maintained by increasing organic carbon.

Rice in general is grown using transplanting of seedlings under puddled field conditions. It requires huge amount of the input energy for the growing the seedlings, transplanting, puddling, irrigation etc. With the advancement in the technology and general agricultural developments, the use of the energy resources has increased markedly. Traditional, low energy farming is being replaced by modern one which requires more energy use. The energy-agriculture relationship is therefore becoming more and more important with the intensification of the cropping systems, which is considered to be the only means of raising agricultural output in land scarce situations. In India, about 28 to
$30 \mathrm{Mt}$ of nutrients $(\mathrm{N}, \mathrm{P}, \mathrm{K})$ are removed from the soil whereas, 18 to $20 \mathrm{Mt}$ are added through all sources, leaving a deficit of about 10 Mt yearly (Singh and Singh, 2003).Therefore, management of organic and mineral fertilizers is, advocated to meet the nutrient needs, improve soil quality, and to obtain sustainable and higher yields. Application of adequate amount and judicious combination of organic and inorganic fertilizers commensurations with the crop needs is considered imperative for realizing sustainable yields of these crops when grown in sequence under limited irrigated (Satyajeet et al., 2007). To optimize the use of organic and mineral sources, information is needed on the rate and pattern of $\mathrm{N}$ and $\mathrm{P}$ mineralization in the soil from organic source (Hadas and Portnoy, 1994). Application of organic source with wide $\mathrm{C}$ : $\mathrm{N}$ ratio may increase the immobilization of fertilizer $\mathrm{N}$, thereby influencing crop availability and $\mathrm{N}$ losses. On the other hand, combining with fertilizer $\mathrm{N}$ lowers the $\mathrm{C}$ : $\mathrm{N}$ ratio of the organic source, leading to an enhanced $\mathrm{N}$ mineralization (Singh et al., 2003). Judicious and efficient nutrient management in cropping system depends on understanding complex interactions between soil and experimental site properties, crop characteristics, climate, and biological processes influencing nutrient dynamics. Preceding and succeeding crop history and other management practices also affect nutrient management strategies. The complexity of the interacting factors indicates that site specific knowledge may be needed for best nutrient management. The in situ soil core technique can be helpful in evaluating management effects on nutrient availability and provide site-specific information needed for improved nutrient management (Kolberg et al.,1997). Crop establishment is also most important concern in this cropping sequence conservation agriculture based ridge-furrow method plays a vital role (Jat et al., 2008, Naresh et al., 2018). Because moisture is the 
principle growing factor for crop production under irrigated conditions, which needs to be conserved for optimization of nutrient use and maximizing the yield advantages of this cropping system (Naresh et al., 2018). Agricultural productivity is closely linked with the carbon and energy efficiency.

Tillage is an energy-intensive farm operation which contributes to $\sim 30 \%$ of the total energy use in crop production (Singh et al., 2008). The consumption of fossil fuel energy is directly related to the emission of GHGs (Yadav et al., 2017), intensive tillage increases the GHGs emissions (Soni et al., 2013). Consequently, a paradigm shift in farm management practices is warranted, involving conservation- effective high EUE and low GHGs emissions practices in agriculture for safe and cleaner production. The conservation agricultural (CA) based-agro-techniques [NT, residue retention, mulching, etc) can reduce the energy use and GHGs emission (Lal, 2015), and increase the soil organic carbon (SOC) pool. Experimental confirmations from wheat-based systems propose that NT and mulch-based elective culturing can yield both short-term e.g., lessened cost of production, improved crop yields, and enhanced water use efficiency (Yadav et al., 2017), and improved soil quality benefits under long run (Meena et al., 2018). Nevertheless, there is significantly less response of NT in rice based cropping systems, rehearsed transcendently by smallholder farms (Babu et al., 2014). Further, reducing fossil fuel consumption and dependency on agro-chemicals may reduce energy input, decrease GHG emissions, reduce the cost of cultivation and enhance the nutrient use efficiency (Meena et al., 2017a) in agricultural production systems. Hence, it is important to evaluate the effects of tillage and mulching practices on $\mathrm{C}$ flow, energy use and economic parameters to better understand the $\mathrm{CF}$ and identify site-specific systems for reducing GHGs released into the atmosphere while also increasing the farm income ( $\mathrm{Lu}$ and Liao, 2016). The present review study was undertaken to find out the best conservation agriculture based crop establishment and efficient nutrient management practices for cereal based cropping system to achieve sustainable and high productivity, carbon and energy efficiencies and sustainable soil health and quality. We also used some examples from subtropical India and summarized key agronomic strategies for reducing the carbon footprint in cereal based system with diverse organic and inorganic fertilizer management options in subtropical environments and to identify energy efficient cereal cropping systems.

\section{Strategies and practices for lowering carbon footprints}

Yadav et al., (2018) also found that the order and share of different components was changed under NT-RR because of reduction in the cost involved in machine operations by $95.1 \%$ (INR 19,400/ha), diesel by $93.7 \%$ (INR 5432/ha), and labor by $2.3 \%$ (INR $800 /$ ha), and increase in cost of plant protection chemicals by $97.2 \%$ (INR 3000/ha) compared with those under CT-RI. The adoption of NT-RR reduced the cost of cultivation of direct-seeded upland ricemustard cropping system by $29.4 \%$ (INR 22,632/ha) over that for the CT-RI (Fig.2). The reduction in the cost of cultivation was primarily due to the exclusion of plowing and leveling expenses under NT-RR. Mulching increased the cost of cultivation by $2-8 \%$ (INR 1295-5135/ha) compared with incurred under the NM. The increase in the cost of cultivation was higher under GM followed by that for the SM because of more labor for carrying and application of mulch materials. Thus, efficient utilization of resources (i.e., energy, water, human labor) through NT-RR and mulch application are feasible options to increase crop productivity and profitability, 
while providing a clean and safe environment to the rural resource-poor farming community in India (Choudhury et al., 2016; Mukherjee, 2010). Therefore, CA (i.e., NT with residue retention and mulch application) is a suitable option for reducing the cost of production, increasing crop productivity, and improving profitability.

The machine operation and diesel consumption are the major energy requiring components of any production systems (Yadav et al., 2017). Therefore, it is necessary to reduce the use and consumption of these components in the production system to overcome the growing energy demands in agriculture. The NT-RR reduced the energy requirement from $27,630 \mathrm{MJ} /$ ha under CT-RI to $16,727 \mathrm{MJ} / \mathrm{ha}$. The reduction in energy input under NT-RR system is mainly because of the exclusion of tillage operations, which consumed a major part of energy inputs used under CT-RI because intensive tillage operations accounted for higher machinery use and fossil fuel consumption (Pratibha et al., 2015).

Gan et al., (2003) also found that diversified cropping systems compared with monoculture systems significantly reduced the production inputs and increased the grain and straw yields of durum wheat. Thus, compared with monoculture systems, durum wheat grown in diversified cropping systems had a lower carbon footprint. Durum wheat preceded by a pulse crop produced grain with a carbon footprint of $0.200 \mathrm{~kg} \mathrm{CO}_{2} \mathrm{e} \mathrm{kg}^{-1}$ of product, $46 \%$ lower than when preceded by a cereal crop. Furthermore, durum wheat had a carbon footprint of $0.301 \mathrm{~kg} \mathrm{CO}_{2} \mathrm{e} \mathrm{kg}^{-1}$ of grain when grown after an oilseed crop $19 \%$ lower than when grown after a cereal (Fig. 3).

Gan et al., (2011) revealed that synthetic $\mathrm{N}$ fertilizers used in the production of a cereal crop contributed the greatest percentage of the carbon footprint, averaging $65 \%$ of the total emissions. The total emission included direct and indirect emissions through volatilization of $\mathrm{NH}_{3}$ and $\mathrm{NO}_{x}$, leaching of nitrate from the application of $\mathrm{N}$ fertilizers on farm fields (27\% of the total emissions), and emissions associated with the production, transportation, storage, and delivery of $\mathrm{N}$ fertilizers to the farm gate $(38 \%)$. The intensity of the emissions associated with $\mathrm{N}$ fertilization depends on the ratio of precipitation to potential evapo-transpiration during the period when the $\mathrm{N}$ fertilizer is applied (Gregorich et al., 2005).

Zhang and Zhang, (2016) reported that the carbon emissions from grain crop production consist of the following four components: (1) emissions from the upstream production and transport of agricultural inputs, (2) direct or indirect emissions induced by various agricultural management processes, (3) emissions from the burning of crop residues and (4) the soil carbon sequestration associated with various production methods (i.e., minimum and no-till practices, straw returning and fertilization) implemented during crop growth. According to LCA theory, the field production carbon footprint includes carbon emissions and carbon sequestration at two points in the production life cycle: the upstream links are associated with the creation of inputs used in agricultural production and processing (i.e., seeds, fertilizer, pesticides, machinery and agricultural film) and the in-field emissions and sequestration are associated with field cultivation (i.e., tillage, sowing, plant protection, harvesting and straw treatment) (Fig. 4a).

Liu et al., (2016) reported that the carbon footprint $(\mathrm{CF})$ of rice production was assessed by considering fertilizer and pesticide consumption, farm-work (plowing, seedling transplantation, fertilizer and pesticide 
spraying, irrigation, and harvest), soil $\mathrm{N}_{2} \mathrm{O}$ and $\mathrm{CH}_{4}$ emissions, soil carbon increment, and energy budget of bio-char production. Carbon cost from straw or bio-char transportation was ignored based on the assumption that the pyrolysis unit for producing bio-char was fed by a local straw supply (Fig.4b).

Yadav et al., (2018) reported that the adoption of NT-RR saved 10,903 $\mathrm{MJ} / \mathrm{ha}$ energy ( 39\%) over that used under CT-RI (Fig. 5). The reduction in energy requirement under NT-RR was mainly due to change in energy consumption pattern for the machinery use and diesel consumption. A total of 6082 $\mathrm{MJ} / \mathrm{ha}(\sim 96 \%)$ of energy was saved by the reduction in machine operations under NTRR over the energy used for the same component under CT-RI (Fig. 5). Similarly, diesel energy use was also reduced by $94 \%$ (5462 MJ/ha) under NTRR over those used for different operations under CT-RI. However, adoption of NT-RR slightly increased the energy used for plant protection chemicals as compared to those for CT-RI. In general, the order of energy use by different inputs under CT-RI was fertilizer > machine > diesel $>$ labor $>$ irrigation $>$ seed $>$ plant protection chemicals, and differed from input energy use order of NT-RR: fertilizer > labor $>$ irrigation $>$ plant protection chemicals > seed $>$ diesel $>$ machine (Fig. 5).

Chen et al., (2014) included carbon emissions from fertilizer production and nitrogen fertilization, but they did not include emissions from manure, pesticides or agricultural films. Zhang et al., (2017) observed that the carbon footprint (emission minus soil carbon sequestration), we found that the three crops emitted more carbon than they sequestered. Of the three main crops in 2013, maize had the lowest carbon footprint, i.e., $4052 \mathrm{~kg}$ ce $/ \mathrm{ha}$ of carbon per unit area or $0.48 \mathrm{~kg}$ ce $/ \mathrm{kg}$ per unit yield. The carbon footprint of wheat was $5455 \mathrm{~kg}$ ce/ha per unit area or $0.75 \mathrm{~kg}$ ce $/ \mathrm{kg}$ per unit yield, while rice had the highest carbon footprint, i.e., 11881 $\mathrm{kg}$ ce/ha per unit area or $1.60 \mathrm{~kg}$ ce/ $/ \mathrm{kg}$ per unit yield. The factors contributing to these emissions varied markedly between crops. Rice yielded the greatest emissions (maximum: $15679 \mathrm{~kg}$ ce/ha) with $45 \%$ consisting of $\mathrm{CH}_{4}$ derived from paddy fields, $21 \%$ from straw burning, $14 \%$ from nitrogen fertilizer, $13 \%$ from fossil fuels for agricultural machinery and $4 \%$ from electricity consumption for irrigation. Wheat exhibited a high carbon emission value of $9119 \mathrm{~kg}$ ce/ha, of which $37 \%$ came from electricity consumption for irrigation, $28 \%$ from nitrogen fertilizers, $25 \%$ from fuel consumption by agricultural machinery and 6\% from straw burning. Maize emitted 7900 $\mathrm{kg}$ ce/ha with $39 \%$ coming from nitrogen fertilizer, $20 \%$ from fuel consumption by agricultural machinery, $18 \%$ from electricity consumption for irrigation and $18 \%$ from straw burning (Fig.6a). However, the carbon footprint of maize production varied substantially among the eight regions in China, ranging from $1192 \mathrm{~kg}$ ce/ha to $9282 \mathrm{~kg}$ ce/ha (Fig. 5b) (the carbon footprint per unit yield ranged from $0.25 \mathrm{~kg}$ ce $/ \mathrm{kg}$ to $0.73 \mathrm{~kg}$ $\mathrm{ce} / \mathrm{kg}$ so that the regions could be divided into four groups.

The greatest carbon footprint was found in V, where the carbon per unit area reached 9282 $\mathrm{kg}$ ce/ha. This result likely stemmed from the high overall carbon emissions (12967 kg ce/ha) and low carbon sequestration $(3685 \mathrm{~kg}$ ce/ha), which can be explained as follows (Fig.6b). (1) The general use of deep ploughing required fossil energy that resulted in high carbon emissions (46\%), particularly when compared to no-till operations; in addition, electricity consumption for irrigation was relatively high. (2) Nitrogen fertilizer inputs were also much greater in this region, averaging $328 \mathrm{~kg} \mathrm{~N} / \mathrm{ha}$. (3) Low temperatures 
and drought conditions reduced the efficiency of soil organic carbon transformation after straw returning.

Yadav et al., (2018) reported that the influence of different factors on GHGs emissions under different tillage and mulch systems indicated that $\mathrm{CO}_{2}$-emissions from $\mathrm{N}_{2} \mathrm{O}$ based estimation contributed the maximum followed by that by the fertilizer use in both the tillage systems. The difference in CF between CT-RI and NT-RR were attributed to the emission from fuel and the input of plant protection chemicals.

The data on $\mathrm{CO}_{2}$-e/ha indicated that NTRR emitted $328 \mathrm{~kg}(\sim 74 \%)$ less GHGs from diesel than those emitted under the CT-RI. However, $\mathrm{CO}_{2}$-e emission was slightly increased with the application of plant protection chemicals under NT-RR as compared to those under CT-RI (Fig.7). Pratibha et al., (2015) also reported that NT has low GHGs emissions as compared to those under CT. $\mathrm{CO}_{2}$-e emission from $\mathrm{N}_{2} \mathrm{O}(\mathrm{N}$ from fertilizer, crop residues, root, and mulch) contributed most to the total GWP, which was approximately 41 and $36 \%$ followed by that through fertilizer use as 37 and 33\% under NT-RR and CT-RI, respectively (Fig.7). Diesel consumption was the third most important contributor to GWP under CT-RI, but these values changed with the adoption of NT-RR system.

The total $\mathrm{CO}_{2}$-e emission was higher under CT-RI (2307 kg CO $\mathrm{CO}_{2}$-e/ha) as compared to those under NT-RR (2013 $\mathrm{kg} \mathrm{CO}_{2}$-e/ha). The differential GWP between NT-RR and CT-RI was due to the difference in the quantity of diesel consumed. The lowest GWP under NTRR was due to savings of fossil fuel from less number of tillage operations and also low emissions associated with energy consumed in manufacture, transport, repair and use of machines (Pratibha et al., 2015).

\section{Energy in rice-wheat cultivation}

Rautaray et al., (2017) observed that the energy input was less by $20.6 \%$ and $28.4 \%$ in SCA in the year 2010 and 2011, respectively, as compared to the CNV (10.2 $\left.\mathrm{GJ} \mathrm{ha}^{-1}\right)$. Low energy input for the SCA was associated with the low input of chemical fertilizers $(43.3 \mathrm{~kg}$ $\mathrm{N}, 6.9 \mathrm{~kg} \mathrm{P}_{2} \mathrm{O}_{5}$ and $13.8 \mathrm{~kg} \mathrm{~K}_{2} \mathrm{O} \mathrm{ha}^{-1}$ ). It was especially important for the nutrient nitrogen with maximum amount saved $\left(43.3 \mathrm{~kg} \mathrm{ha}^{-1}\right)$ and highest energy equivalent (60.6 MJ per $\mathrm{kg}$ nitrogen) as compared to phosphorus and potash. Also, there was save in energy (447 $\mathrm{MJ})$ due to less labour requirement for hand weeding possibly due to allelopathic effects of Sesbania on weed population. Energy required for growing rainfed Sesbania with the existing practice of summer ploughing was very low (294 MJ towards seed and 23.5 MJ ha ${ }^{-1}$ as human energy for seeding) as compared to energy saved through chemical fertilizers (2793 MJ) and less weeding (447 MJ). Ramchandra and Nagarathna (2001) reported that energy input for rice cultivation in the coastal zone of Uttara Kannada district was $22.2 \mathrm{GJ}^{-1}{ }^{-1}$, out of which $13.59 \mathrm{GJ}^{-1}$ was due to addition of FYM alone. Thus, energy input in their study was $8.61 \mathrm{GJ} \mathrm{ha}^{-1}$ without considering the energy input through FYM. Net energy in the SCA (135.4 and $138.8 \mathrm{GJ} \mathrm{ha}^{-1}$ in the first and second year, respectively) was higher as compared to CNV. Also, the energy output: input ratio and energy productivity were higher for the SCA. These parameters indicate higher energy efficiency in case of SCA as compared to CNV. Saikia et al., (2004) reported energy output: input ratio of 13.5 which is close to the value for the treatment CNV (14.0). Higher ratio (17.7 and 20.0 in the first and second year, respectively) for SCA in this experiment is mainly due to saving in chemical fertilizers and less labour requirement in weeding. 
Rajesh et al., (2018) revealed that the source wise energy consumption with percentage share for rice is presented in Fig. 8a. It is clear from these figures, electricity (34\%) was a highest input followed by fertilizer (33\%), diesel (19\%), farmyard manure (4\%), human (4\%), machinery (including tractor) (3\%), seed $(1 \%)$ and chemical $(2 \%)$. Total input energy involved for rice was $23773.84 \mathrm{MJ} / \mathrm{ha}$. The component of commercial energy was found to be highest (93\%) and rest was noncommercial energy. The energy from direct, indirect, renewable and non-renewable sources was 57, 43, 9 and 91\%, respectively. Moreover, the percentage source wise energy share for raising wheat is presented in Fig. 8b. It is clearly shown that fertilizer $(36 \%)$ was a major source of energy followed by diesel $(28 \%)$ electricity (19\%) and seed (8\%). The remaining was chemical (4\%), farmyard manure $(3 \%)$, machinery (including tractor) $(1 \%)$ and human $(1 \%)$.

Parihar et al., (2018) also found that tillage practices the mean total energy of $119764 \mathrm{MJ}$ $\mathrm{ha}^{-1}$ was consumed in zero tillage flat planting (ZT) followed by in permanent bed planting (116294 MJ $\mathrm{ha}^{-1}$ ) and the least in conventional tillage (CT, $115787 \mathrm{MJ} \mathrm{ha}^{-1}$ ) (Fig. 9a). Maximum renewable energy and non-renewable input energy (132957 MJ ha $\left.{ }^{-1}\right)$ was recorded under MMS rotation followed by $\mathrm{MWMb}$ as compared to other cropping systems (MMuMb and MMS). Overall, renewable energy through crop residues biomass contributed maximum input energy followed by non-renewable resources viz., diesel, fertilizers, chemicals and machineries. The percentage share of these input energy resources followed the order with the highest by crop residues (72.6\%), followed by fertilizers $(14.8 \%)$, diesel $(6.8 \%)$, water (1.6\%), seeds (1.3\%), human labors (1.3\%) plant protection chemicals $(1.1 \%)$, and the least by machineries (0.5\%) (Fig. 9b). Further, the trend of operation-wise input energy utilization showed that the highest energy was consumed in residue application $(71.9 \%)$ followed by fertilizer (15.3\%), irrigation $(5.8 \%)$, land preparation and sowing (3.7\%), harvesting and threshing (1.8\%), herbicide application $(0.8 \%)$, and the least by plant protection (0.3\%) (Fig. 9c). These energy utilization patterns of either sourcewise or operation-wise may be due to less mechanization and more use of human/animal power in Indian agriculture (Fig. 9b and 9c). This might be due to carbon inputs and outputs were remarkably influenced by the tillage and nutrient management practices. The increment in total energy was 32.4, 13.9 and $13.3 \%$ over control and sole application of FYM at 6t/ha while the energy efficiency $(12.78 \mathrm{MJ} / \mathrm{ha})$ and energy productivity (0.98 $\mathrm{MJ} / \mathrm{ha}$ ) was maximum with sole application of FYM at 6t/ha while the energy efficiency energy productivity and energy intensity were shown reverse trend with increasing fertility levels and observed highest with control and lowest with highest fertility level.

Soni et al., (2018) revealed that direct energy contributed $30.81 \%$ and $24.84 \%$ of the total energy input in the paddy-wheat (PW) and paddy-potato (PP) cropping systems, respectively. Renewable energy use was higher in PP systems, with a contribution of $21.66 \%$ compared to $9.59 \%$ in the PW system. The higher renewable energy input in the PP system can be explained by the higher human and animal energy input in the system. Fig. 10a and 10b illustrate the share of direct and indirect energy inputs and the output energy in the two systems. India is an important agricultural country, producing $22.3 \%, 11.78 \%$, and $2 \%$ of global rice, wheat, and maize grains, respectively (FAO, 2017). India is also the largest emitter of agricultural GHG emissions, accounting for $13.0 \%$ of global total agricultural emissions (FAO, 2017). In recent decades, India's agricultural output has increased due to high input rates of 
pesticides and fertilizers but with the little adoption of conservation agriculture (CA). India has announced that by 2020 it will reduce carbon dioxide emissions per unit of GDP by 20 to $25 \%$ and by $30-35 \%$ in 2030 , compared to the 2005 level.

Parihar et al., (2018) reported that tillage practices residue plus fertilizer application consumed major (76-81\%) input energy, of which residue application consumed about 43.7-49.8\% and fertilizer application consumed about 31.2-32.4\%. CA based (ZT and $\mathrm{PB}$ ) planted cereal crop consumed $3-5 \%$ less energy, compare to conventionally tilled (Fig. 11a). However, fertilizer use was the second most important energy contributor with $29-36 \%$ share in total input energy, and rest all other operations consumed about 17$22 \%$ of input energy (Fig. 11b). Energy consumed in the residue application varied due to retention/ incorporation of differential amount of residue biomass in different tillage (ZT, PB and CT) and diversified crop rotations (MWMb, MCS, MMuMb and MMS) treatments. Retention/ incorporation of crop residue have several advantages like better soil health, higher crop productivity and improved environmental quality. Further, the crop residue is a renewable energy source and can also supplement plant nutrients without any negative impact on crop productivity. This might be due to less consumption of water, labour, and fuel for irrigating in the PB plots than to CT plots and also the surface retention of crop residue in $\mathrm{CA}$ based $\mathrm{PB}$ and ZT systems helped in lowering down the evaporation losses and hence conserving more soil moisture (Parihar et al., 2016; Jat et al., 2013; Aggarwal and Goswami, 2003).

Irrespective of tillage and crop establishment in winter season crops, residue application contributed maximum $(61-87 \%)$ to the total input energy. While, the next energy consuming operation was fertilizer application (5-21\%) followed by irrigation (3$11 \%$ ) and land preparation and sowing (1.2$6.6 \%)$. However, herbicide application and inter-culture operation adopted to control the weeds in CT plots consumed 98-101\% less input energy than CA based ZT and PB plots. Liu et al., (2016) also found that the wheat in the continuous wheat system produced the highest grain yield and gained highest soil organic carbon over the years, leading to the smallest footprint value at $-0.441 \mathrm{~kg} \mathrm{CO}_{2} \mathrm{eq}$ $\mathrm{kg}^{-1}$ of grain, significantly lower than the footprint for the other three systems which ranged between -0.102 to $-0.116 \mathrm{~kg} \mathrm{CO}_{2} \mathrm{eq}$ $\mathrm{kg}^{-1}$ of grain.

Jat et al., (2019) also found that the cropping systems (MMuMb and $\mathrm{MWMb}$ ) remained at par with respect to yield within same tillage and residue management practices. However, crops planted on PB with residue registered $11.7 \%$ increase in system productivity compared to PB-R. Highest PEY (1.91 $\mathrm{Mg} / \mathrm{ha}$ ) and APE (87.4 adult/ha/year) were registered in $\mathrm{MWMb}$ under $\mathrm{PB}+\mathrm{R}$ and $\mathrm{N}$ through NCU (Fig. 12a). Among N management treatments, highest system productivity was recorded in $\mathrm{N}$ through NCU in $\mathrm{PB}+\mathrm{R}$ and $\mathrm{PB}-\mathrm{R}$ being at par with $\mathrm{N}$ through $\mathrm{PU}$ under $\mathrm{PB}-\mathrm{R}$ and $\mathrm{N}$ through $\mathrm{SCU}$ under $\mathrm{PB}+\mathrm{R}$. $\mathrm{N}$ management through Neem coated urea (NCU) recorded 2.3 and 10.9\% higher system productivity compared with non-coated prilled urea plot under $\mathrm{PB}-\mathrm{R}$ and $\mathrm{PB}+\mathrm{R}$, respectively. In general, the superiority of coated urea materials over PU is due to the slow release of nitrogen through the coating, synchronized with the nitrogen need of the growing plants.

Nitrogen is released slowly and is absorbed and utilized by the plants effectively, hence with minimization of losses; crop use increases and simultaneously the system productivity. Neem oil extracted from seed kernels contains various kind of bitter, 
especially the meliacins that have been identified in retarding the process of nitrification of Urea. The bio-molecules having antibacterial action against Gram negative and Gram-positive microorganisms act as an active Nitrification Inhibitors. In this way, NCU maintained superiority over other coated materials due to its nitrification inhibiting character which suppressed the rate of formation and leaching loss of $\mathrm{N}_{\text {as }} \mathrm{NO}_{3}{ }^{-}$. Neem cake has acidic properties which also retarded the volatilization loss of $\mathrm{NH}_{3}$ through reducing the alkalinity of the medium in the immediate vicinity of urea prills. Gagnon et al., (2012) and Sanjay-Kumar et al., (2015) had also similar finding for the effectiveness of coated fertilizer towards a higher yield of ZT maize.

Fig.1 Soil and GHGs fluxes (adapted from Ciais et al., 2013)

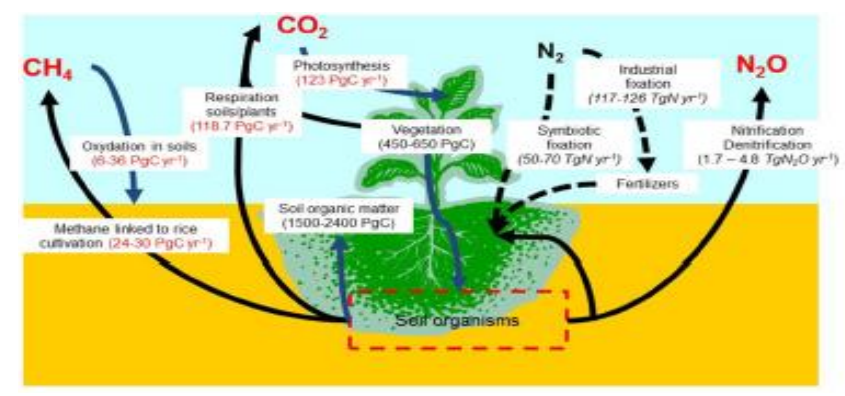

Fig.2 Share of different component of cost of cultivation and cost saving over respective component under different tillage practices (CT-Conventional tillage; NT-No-till; RI-100\% residue incorporation; RR-100\% residue retention)

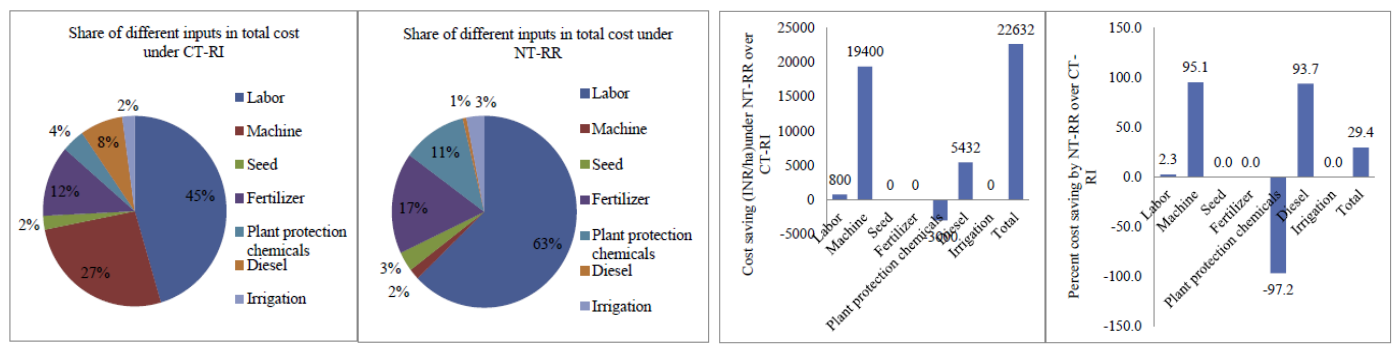

Fig.3 Conventional and diversified rotations differ in the type and timing of weed management practices, seeding dates, and canopy characteristics (adopted from Gan et al., 2010)
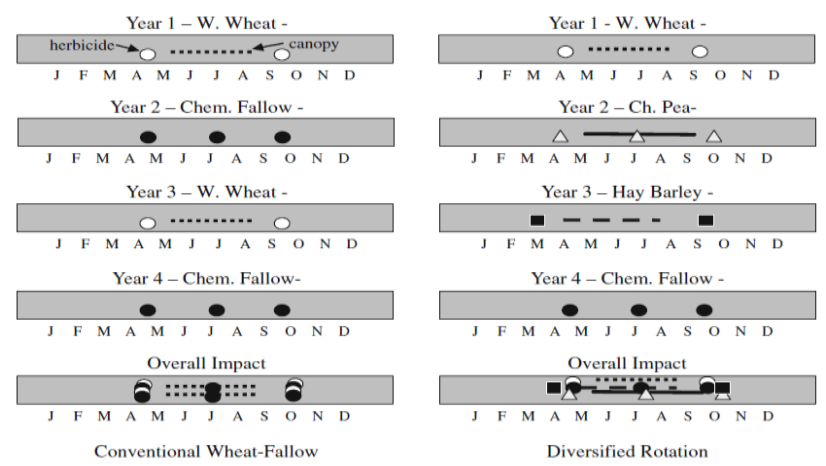
Fig.4 (a) A theoretical model of the carbon footprint of crop production (adopted from Zhang and Zhang, 2016); (b) Carbon footprint budget in one life cycle of crop production under biochar amendment. Carbon footprint $=\mathrm{CO}_{2}$-Ce sources $-\mathrm{CO}_{2}-\mathrm{Ce}$ sinks. $\mathrm{CO}_{2}-\mathrm{Ce}$ sources involve plowing, sowing, irrigation, fertilizer and pesticide input, harvest, soil $\mathrm{N}_{2} \mathrm{O}$ and $\mathrm{CH}_{4}$ emissions and total electric energy cost for pyrolysis process (adopted from Liu et al., 2016)

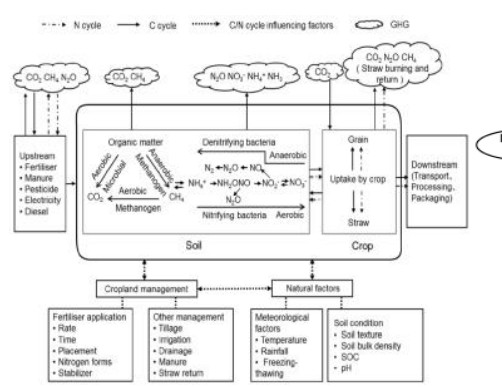

(a)

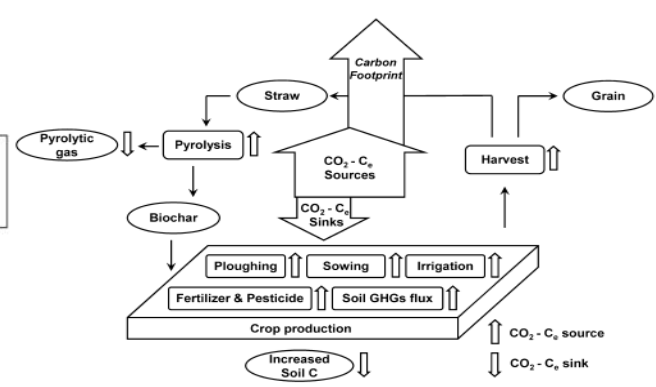

(b)

Fig.5 Share of different component of energy and energy saving over respective component under different tillage (CT- Conventional tillage; NT-No-till; RI- 100\% residue incorporation; RR-100\% residue retention)

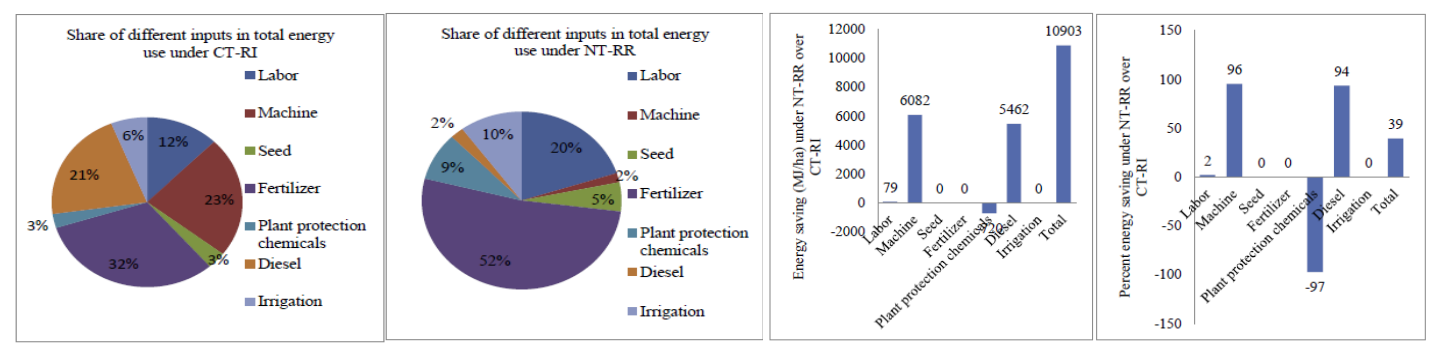

Fig.6 (a) Carbon emission and carbon sequestration components per unit area/yield for the three primary grain crops; (b) Distribution of carbon emissions and carbon sequestration among the three main crops in different areas "Other emission" includes emissions from the upstream production and transport of agricultural inputs (such as chemical fertilizer, agricultural film, pesticides and manure)

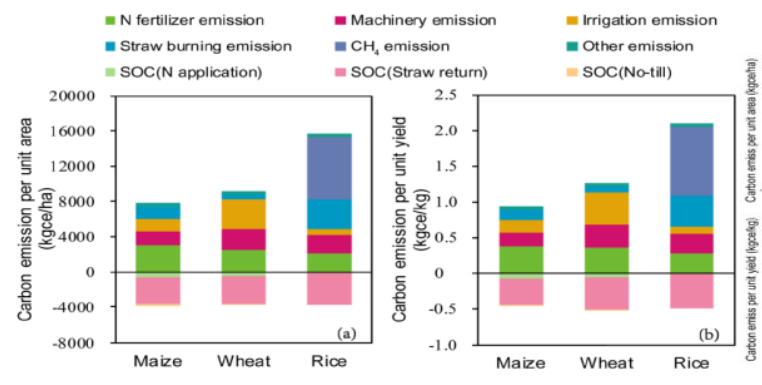

(a)

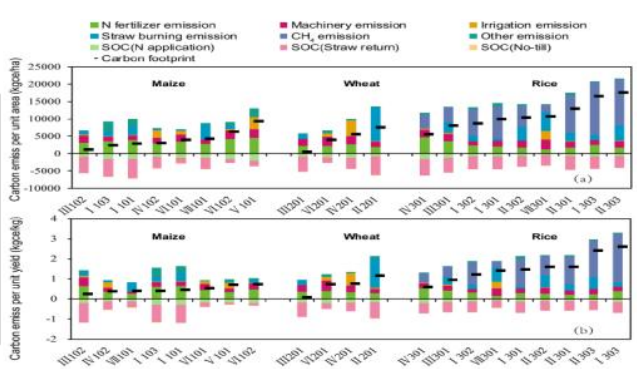

(b) 
Fig.7 Share of different inputs of component carbon footprint and reduction in carbon footprint under different inputs (CT- Conventional tillage; NT-No-till; RI- 100\% residue incorporation;

$\mathrm{RR}-100 \%$ residue retention

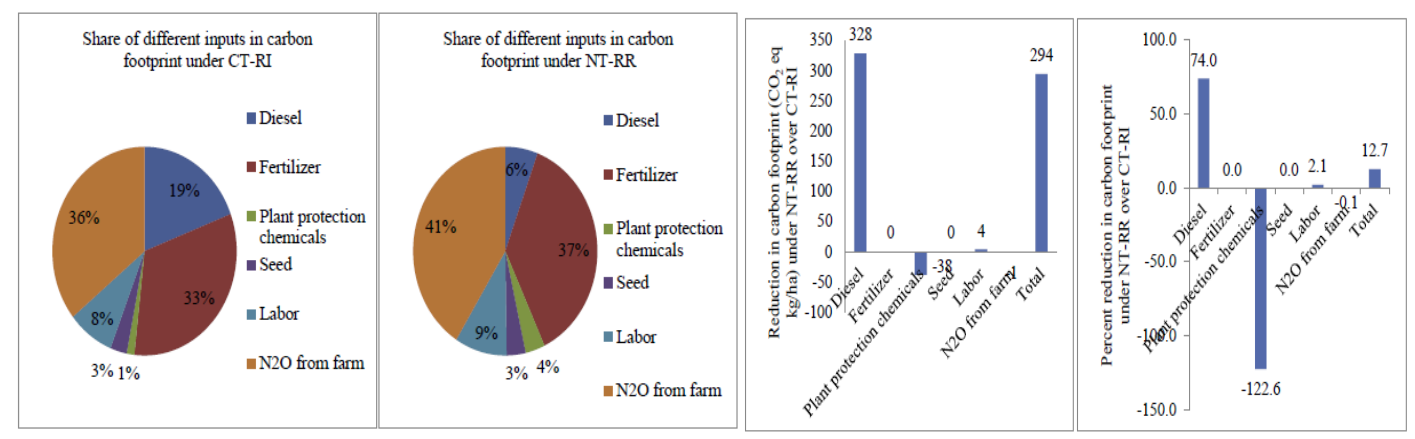

Fig.8 (a) Source Wise Energy Consumption for Raising Rice; (b) Source Wise Energy Consumption Percentage Share for Wheat

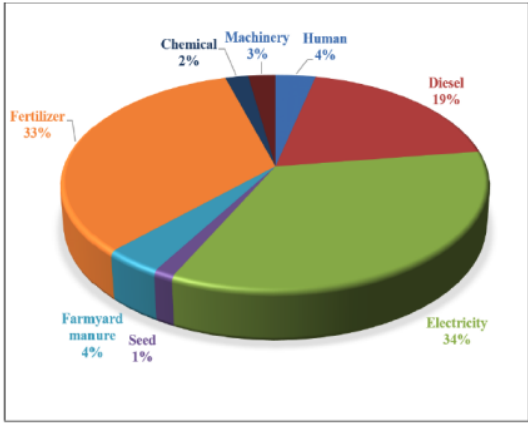

(a)

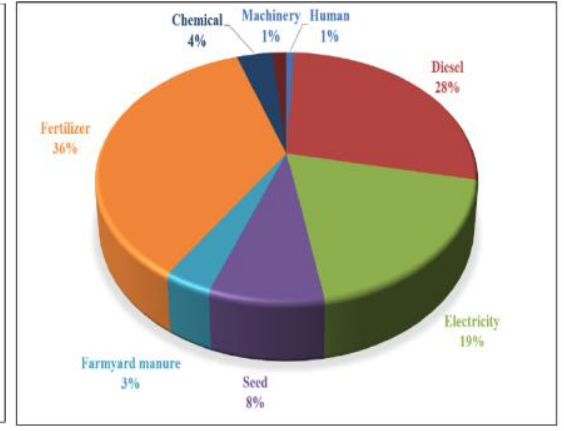

(b)

Fig.9 (a) Renewable and non-renewable input energy $\left(\mathrm{MJ} \mathrm{ha}^{-1}\right)$ under different tillage practices (b) Source-wise input energy in contrasting tillage and cereal based cropping system (c) Operation-wise input energy in contrasting tillage and cereal based cropping systems

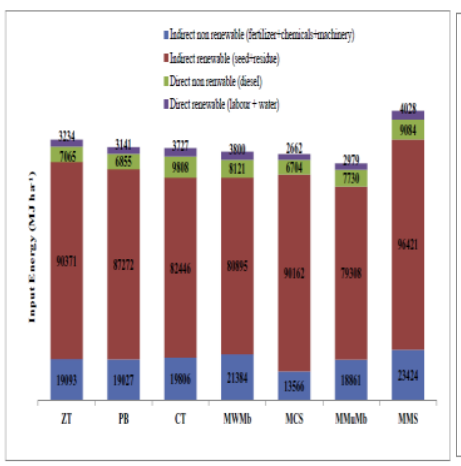

(a)

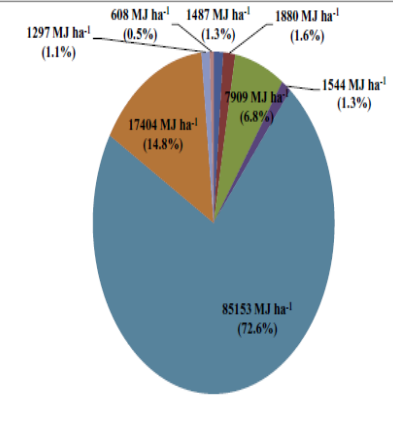

(b)

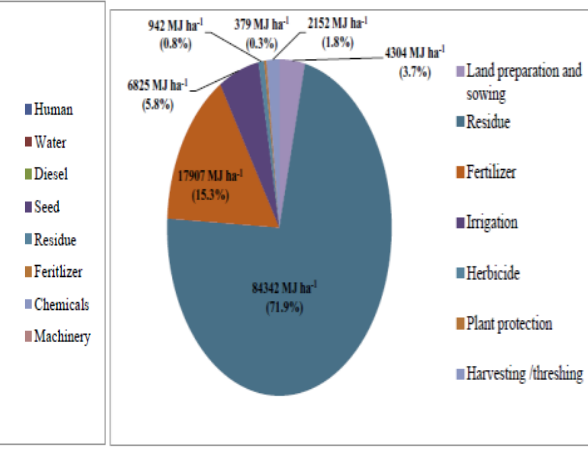

(c) 
Fig.10 (a) Share of direct and indirect energy sources to total input energy, and output energy of paddy-wheat system; (b) Share of direct and indirect energy sources to total input energy, and output energy of paddy-potato system

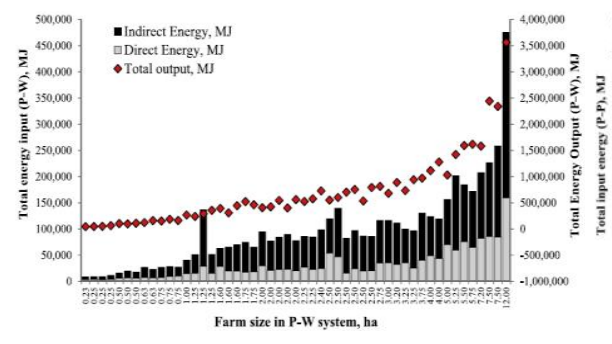

(a)

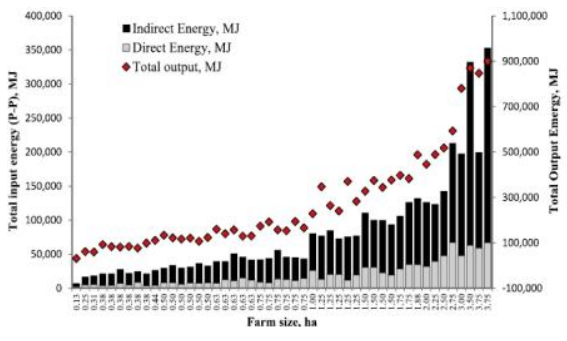

(b)

Fig.11 (a) Operation-wise input energy-use (\%) under contrasting tillage practices (a) cropping systems (b)

Fig.11 (b) Source-wise input energy-use (\%) under contrasting tillage practices (a) cropping systems (b)

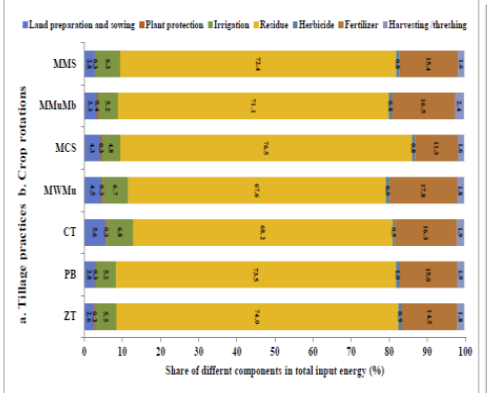

(a)

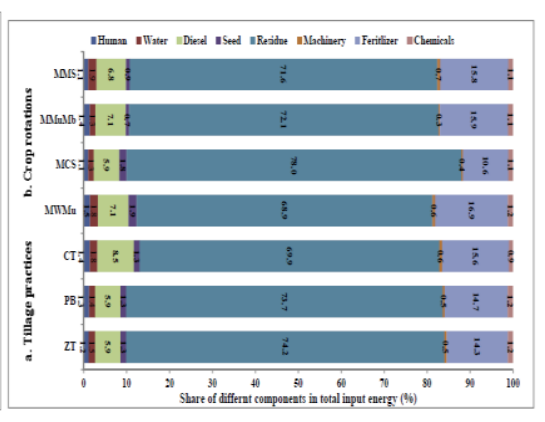

(b)

Fig.12 (a) Share of different farming operations in energy input of maize-mustard-mungbean $(\mathrm{MMuMb})$ and maize-wheat-mungbean $(\mathrm{MWMb})$ cropping systems under tillage, residue and nitrogen management practices; (b) Share of different inputs towards carbon footprints of maizemustard-mungbean $(\mathrm{MMuMb})$ and maize-wheat-mungbean $(\mathrm{MWMb})$ cropping systems under various tillage, residue and nitrogen management practices

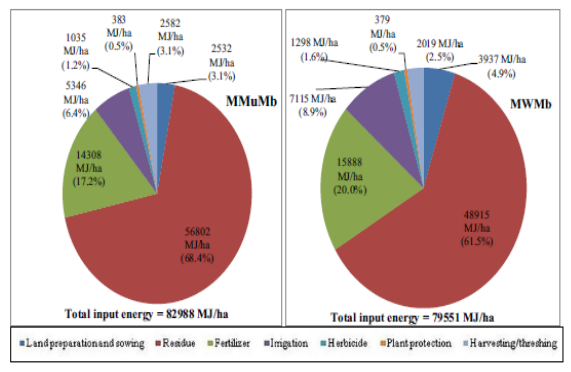

(a)

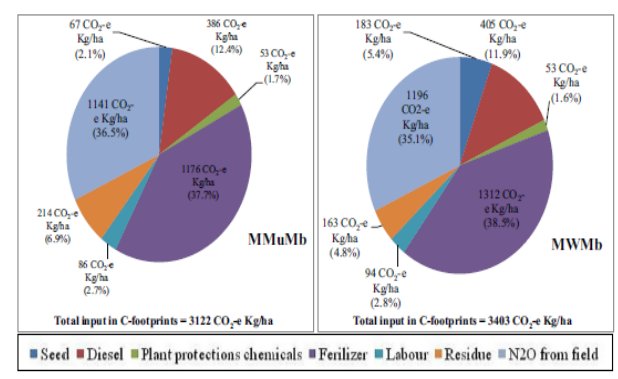

(b) 
Fig.13 (a) Labile and recalcitrant carbon pools in bulk soils and aggregates as affected by longterm fertilization in the $0-15$ and $15-30 \mathrm{~cm}$ soil layers under a wheat based cropping system in an Inceptisol; (b) Enrichment factor of soil organic C (SOC) in aggregates as affected by 44 years of fertilization under wheat based cropping system in an Inceptisol

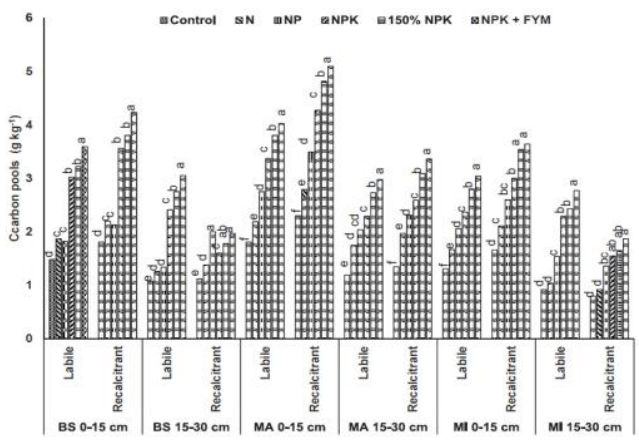

(a)

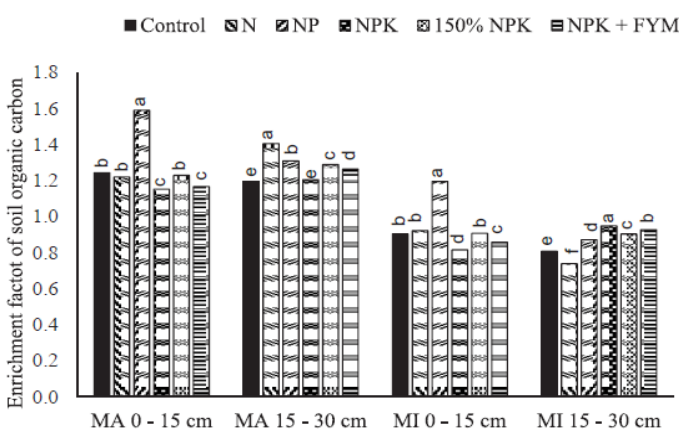

(b)

Fig.14 (a) Carbon intensity (CI) of rice production under bio-char amendment in response to net electric energy input of bio-char production $\left(\mathrm{E}_{\text {net }}\right)$ and half-life of bio-char-carbon $\left(\mathrm{T}_{1 / 2}\right)$; (b) Estimation of annual carbon mitigation potential via transformation of straw into bio-char

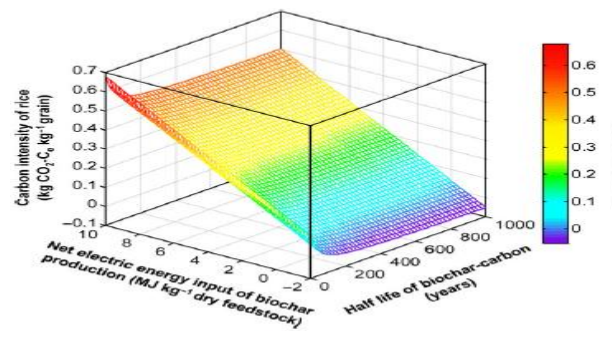

(a)

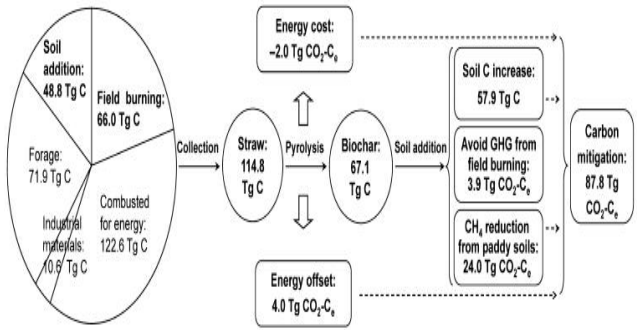

(b)
Jat et al., (2019) observed that Irrespective of residue retention the mean total energy of 82,988 and $79,551 \mathrm{MJ} / \mathrm{ha}$ was used in the $\mathrm{MMuMb}$ and $\mathrm{MWMb}$ rotations, respectively (Fig.12b). Largely, crop residues contributed highest energy input 68.4 and $61.5 \%$ in $\mathrm{MMuMb}$ and $\mathrm{MWMb}$ cropping system, respectively. Next to it, the major energy demanding operation is fertilizer application, it accounts for about $17.2 \%$ of total energy in $\mathrm{MMuMb}$ and $20.0 \%$ in MWMb.

Parihar et al., (2017a) described crop residue management as most energy demanding operation (71-89\%) in maize-based cropping system. MWMb required $1405 \mathrm{MJ} / \mathrm{ha}$ more energy for land preparation and sowing compared to $\mathrm{MMuMb}$. Similarly, irrigation operation in MWMb consumed about 1769 $\mathrm{MJ} / \mathrm{ha}$ more energy than MMuMb. This was mainly because, wheat cultivation in MWMb cropping system required more irrigations than mustard. Among various $\mathrm{N}$ management practices total energy requirement was highest in plots under $\mathrm{N}$ application through $\mathrm{NCU}$ (149,068 MJ/ha), followed by $\mathrm{N}$ through SCU $(146,512 \mathrm{MJ} / \mathrm{ha})>\mathrm{N}$ through PU $(141,887$ $\mathrm{MJ} / \mathrm{ha}) \mathrm{N}$ unfertilized $(98,527 \mathrm{MJ} / \mathrm{ha})$ in $\mathrm{PB}+\mathrm{R}$ practice.

Ghosh et al., (2018) also found that the plots with NPK+FYM had significantly higher labile $\mathrm{C}$ within macro-aggregates compared with NPK and control plots (Fig. 13a). 
However, labile $\mathrm{C}$ concentrations within macro-aggregates of $150 \%$ NPK and NPK+FYM were similar. Labile: recalcitrant $\mathrm{C}$ in macro-aggregates of NPK+FYM was 1.38:1. There was a gradual decrease in labile $\mathrm{C}$ within macro-aggregates in $\mathrm{NP}, \mathrm{N}$ and control plots. Similarly, recalcitrant C closely followed the trend of labile $\mathrm{C}$ within macroaggregates, except under NP plots, which had significantly less labile $\mathrm{C}$ within macroaggregates than all other plots. However, macro-aggregates of NPK+FYM had 19\% and $46 \%$ higher recalcitrant $C$ than NPK and $\mathrm{NP}$ plots. Like labile $\mathrm{C}$ within macroaggregates, $150 \%$ NPK and NPK+FYM plots had similar recalcitrant $\mathrm{C}$ pools. Similar trend of $\mathrm{C}$ concentration was observed within micro-aggregates, as was observed within macro-aggregates. Moreover, labile recalcitrant $\mathrm{C}$ in bulk soils and microaggregates of NPK, $150 \%$ NPK and NPK+FYM plots were similar and significantly higher than control, $\mathrm{N}$ and $\mathrm{NP}$ plots, and signifying higher rate of $\mathrm{C}$ sequestration in the former treatments than the latter ones in sub-surface layer. Labile: recalcitrant $\mathrm{C}$ ratios within macro-aggregates were similar for all treatments. When expressed on a total soil basis, macroaggregates accounted larger part of total SOC in surface and subsurface soil layers. Interestingly, macro-aggregates of NP plots in soil surface had 1.36 and 1.38 times greater SOC enrichment than NPK+FYM and NPK treated plots. Whereas, macro-aggregates from $\mathrm{N}$ plots had 1.12 and 1.18 times greater $\mathrm{C}$ enrichment than NPK+FYM and NPK plots, respectively, in sub-surface soil. Carbon enrichment factor of soil micro-aggregates from all plots were $<1$, indicating net $\mathrm{C}$ depletion (Fig. 13b). The increased labile $\mathrm{C}$ content with application of fertilizers and manure could be because of the priming effect of applied nutrients on fresh organic materials in the soils. All these amendments stimulate the microbial activity helping SOC decomposition due to rapid excretion of the labile C (Tripathi et al., 2014).

Petersen et al., (2006) tracked $\mathrm{N}_{2} \mathrm{O}$ emissions from five rotation sequences and found $\mathrm{N}_{2} \mathrm{O}$ emissions were lower from the organic than conventional crop rotations, ranging from 4.0 $\mathrm{kg} \mathrm{N}_{2} \mathrm{O}-\mathrm{N} \mathrm{ha}^{-1}$ to $8.0 \mathrm{~kg} \mathrm{~N}_{2} \mathrm{O}-\mathrm{N} \mathrm{ha}^{-1}$ across all crops as total $\mathrm{N}$ inputs increased from 100 to $300 \mathrm{~kg} \mathrm{~N} \mathrm{ha}^{-1} \mathrm{yr}^{-1}$. Robertson et al., (2000) compared the net global warming potential (GWP) of conventional tillage, no-till, low input and organic management of a corn soybean-wheat system over 8 yrs. After converting the combined effects of measured $\mathrm{N}_{2} \mathrm{O}$ production, $\mathrm{CH}_{4}$ oxidation and $\mathrm{C}$ sequestration, plus the $\mathrm{CO}_{2}$ costs of agronomic inputs to $\mathrm{CO}_{2}$ equivalents ( $\mathrm{g}$ $\mathrm{CO}_{2} \mathrm{~m}^{-2} \mathrm{yr}^{-1}$ ) none of the systems provided net mitigation, and $\mathrm{N}_{2} \mathrm{O}$ production was the single greatest source of GWP. The no-till system had the lowest GWP (14), followed by organic (41), low input (63) and conventional (114). Cavigelli et al., (2009) also calculated was the greenhouse gas intensity (GHGI = GWP per unit of grain yield). The contribution of energy use to GWP was 807, 862, and 344 in NT, CT, and $\mathrm{Org} 3$, respectively. The contribution of $\mathrm{N}_{2} \mathrm{O}$ flux to GWP was 303, 406, and $540 \mathrm{~kg} \mathrm{CO} \mathrm{CO}_{2} \mathrm{e}$ $\mathrm{ha}^{-1} \mathrm{y}^{-1}$ in NT, CT and Org3, respectively. The contribution of change in soil $\mathrm{C}$ to GWP was 0,1080 , and $-1953 \mathrm{~kg} \mathrm{CO}_{2} \mathrm{e} \mathrm{ha}^{-1} \mathrm{y}^{-1}$ in NT, CT and Org3, respectively. GWP (kg $\mathrm{CO}_{2} \mathrm{e} \mathrm{ha}^{-1} \mathrm{y}^{-1}$ ) was positive in NT (1110) and CT (2348) and negative in Org3 (-1069), primarily due to differences in soil $\mathrm{C}$ and secondarily to differences in energy use among systems. Despite relatively low crop yields in $\mathrm{Org} 3$, GHGI $\left(\mathrm{kg} \mathrm{CO}_{2} \mathrm{e} \mathrm{Mg}\right.$ grain $\left.^{-1}\right)$ for $\mathrm{Org} 3$ was also negative $(-207)$ and significantly lower than for NT (330) and CT (153). Org3 was thus a net sink, while NT and CT were net sources of $\mathrm{CO}_{2} \mathrm{e}$. The authors concluded that common practices in organic systems including soil incorporation of 
legume cover crops and animal manures can result in mitigation of GWP and GHGI relative to NT and CT systems, primarily by increasing soil $\mathrm{C}$.

Dyer and Desjardins (2005) reported that GHG emissions for secondary tillage operations, such as discing that would require more draft power than finger weeders, as low $\left(\sim 28 \mathrm{~kg} \mathrm{CO} \mathrm{Ca}^{-1}\right)$ compared to plowing (90 28 $\mathrm{kg} \mathrm{CO}_{2} \mathrm{ha}^{-1}$ ) and between two to three times that for spraying $(\sim 10 \mathrm{~kg}$ $\mathrm{CO}_{2} \mathrm{ha}^{-1}$ ). Manure spreading is also a relatively low E requiring practice. Bos et al., (2010) also found that the energy requirements for imported organic manures were restricted to those for transport and application only and a 'zero energy' price for organic manures themselves was assumed. Consequently, E use was lower for a crop fertilized mainly with organic fertilizers than for a crop fertilized mainly with mineral fertilizers. On farms, manure (or compost) application is a relatively low fuel and $\mathrm{E}$ cost (<10 $\mathrm{kg} \mathrm{CO} \mathrm{CO}_{2} \mathrm{ha}^{-1}$ ) when compared with tillage operations $\left(>80 \mathrm{~kg} \mathrm{CO}_{2} \mathrm{ha}^{-1}\right.$ and $>28$ $\mathrm{kg} \quad \mathrm{CO}_{2} \mathrm{ha}^{-1}$ for plowing and discing respectively) and harvesting (>33 kg $\mathrm{CO}_{2} \mathrm{ha}^{-1}$ ).

Liu et al., (2016) revealed that bio-char was applied into soil, net electric energy input of bio-char production ( $\mathrm{E}$ net) and half-life of bio-char- carbon $\left(\mathrm{T}_{1 / 2}\right)$ are two of the most critical factors in influencing carbon footprint value in agricultural activities. CI of rice production under bio-char amendment has a positive and negative relationship with $\mathrm{E}_{\text {net }}$ and $\mathrm{T}_{1 / 2}$, respectively (Fig.14a). However, based on the lowest energy consumption pattern of bio-char production in current study, a rough estimation on net carbon mitigation under bio-char strategy was about 87.8 $\mathrm{Tg} \mathrm{CO}_{2}$-Ce $\mathrm{yr}^{-1}$ by considering available straw source, soil carbon sequestration, avoided straw field-burning, and soil $\mathrm{CH}_{4}$ reduction from paddy soils (Fig.14b). This value is higher than a previous estimate of 20.5-55.9 $\mathrm{Tg} \mathrm{CO}_{2}-\mathrm{Ce} \mathrm{yr}^{-1}$ reported by Dickie et al., (2014).

In conclusions the intensive agricultural production systems rely on fossil fuel burning for energy management and having a lion share in the energy input and GHGs emissions. The fossil fuel based $\mathrm{CO}_{2}$ emissions are major contributors to energy input and GWP in agro-ecosystems. Hence, high water and fertilizer inputs as well as the operation of machinery for agricultural purposes not only induced soil $\mathrm{N}_{2} \mathrm{O}$ and $\mathrm{CH}_{4}$ emissions but resulted in considerable consumption of energy from fossil fuels. Straw burning further increased the carbon emissions of these grain crops. It is recommended that intermittent irrigation be optimized to reduce the emission of $\mathrm{CH}_{4}$ from rice paddies and that the irrigation of wheat, nitrogen fertilizer management for maize and straw returning for rice and maize be optimized to reduce the carbon footprint of these crops. The carbon balance can be an indicator of agricultural production efficiency, soil fertility and environmental pollution. So identifying the carbon footprint of a crop is an important component of sustainable agriculture. In aspects of carbon and energy efficiency the scope of diverse organic has immense importance, as it has the potential to replace a part of chemical fertilizer and then farming will be more dependent on renewable sources.

Clear and significant differences exist in energy and GHG emission performance between organic and conventional operations. Organic generally has lower energy use and GHG emissions $\mathrm{ha}^{-1}$, better energy input/output ratios per unit of product, but variable results for energy use and GHG emissions per unit of product. With some variability in results for field crops with 
organic systems are consistently more energy efficient, beyond a 20\% threshold, than conventional systems. Life cycle assessment on carbon footprint of crop production in biochar-managed agro-ecosystem provided an insight into bio-char's role in the contribution of each process to carbon equivalent emissions. Based on pyrolytic gas-recycled pyrolysis technique with low energy cost, biochar amendment could reduce carbon footprint of rice production compared with conventional straw return management, benefiting from significant soil carbon sequestration and reduced $\mathrm{CH}_{4}$ emissions. In CA systems, crop residues contributed the maximum $(\sim 76 \%)$ in total energy input $\left(167,995 \mathrm{MJ} \mathrm{ha}^{-1}\right)$; however, fertilizer application (nonrenewable energy source) contributed the maximum $(43 \%)$ in total energy input $\left(47,760 \mathrm{MJ} \mathrm{ha}^{-1}\right)$ in CT-based systems. CA-based cereal (rice/maize) systems recorded higher net energy and energy-intensiveness (EI) levels of $251 \%$ and $300 \%$, respectively, compared with those of the CT-based rice-wheat system (RW/CT). There are huge gaps between the development of new cropping technologies and the implementation of the technologies in farming operations. Therefore in future, the synergistic combinations of the more diverse organic and inorganic fertilizer management options suitable for particular crop and cropping systems must be explored under CA to achieve the sustainable development growth

\section{References}

Aggarwal, P., and Goswami, B. 2003. Bed planting system for increasing water use efficiency of wheat grown on Inceptisol. Indian J Agric Sci., 73: 422-425.

Bos, J.F.F.P., de Haan, J.J., Sukkel, W., and Schils, R.L.M. 2010. Comparing energy use and greenhouse gas emissions in organic and conventional farming systems in The Netherlands.
Proceedings of the Third QLIF Congress, Hohenheim, Germany, 20-23 March 2007; Available online: http://orgprints.org/view/projects /int_conf_qlif2007.html (accessed on 29 October 2010).

Cavigelli, M.A., Djurickovic, M., Rasmann, C., Spargo, J.T., Mirsky, S.B., and Maul, J.E. 2009. Global warming potential of organic and conventional grain cropping systems in the Mid-Atlantic Region of the US. Proceedings of the Farming System Design Conference, Monterey, CA, USA, 25 August 2009.

Chen,X.et al.2014. Producing more grain with lower environmental costs. Nature 514: 486-489.

Choudhury, B.U., Fiyaz, A.R., Mohapatra, K.P., and Ngachan, S. 2016. Impact of land uses, agro-physical variables and altitudinal gradient on soil organic carbon concentration of north-eastern Himalayan region of India. Land Degrad. Dev. 27: 1163-1174

Ciais, P., Sabine, C., Bala, G., Bopp, L., Brovkin, V., Canadell, J., et al., 2013. Carbon and other biogeochemical cycles in Climate Change 2013: The Physical Science Basis. Contribution of Working Group I to the Fifth Assessment Report of the Intergovernmental Panel on Climate Change, eds T. F. Stocker, D. Qin, G.-K. Plattner, M. Tignor, S. K. Allen, J. Boschung, A. Nauels, Y. Xia, V. Bex, and P.M. Midgley (Cambridge, UK; New York, NY: Cambridge University Press), 465-570.

Dyer, J.A., and Desjardins, R.L. 2005. A simple meta-model for assessing the contribution of liquid fossil fuel for onfarm fieldwork to agricultural greenhouse gases in Canada. J. Sustain. Agr. 27: 71-90.

Gagnon, B., Ziadi, N., and Grant, C. 2012. Urea fertilizer forms affect grain corn yield and nitrogen use efficiency. Can. J. 
Soil Sci. 92: 341-351.

Gan YT, Kutcher R, Menalled F, Lafond L, and Brandt S. 2010. Crop diversification and intensification with broadleaf crops in cereal based cropping systems in the Northern Great Plains of North America. In: Malhi SS, Gan YT, Schoenau JJ, Lemke RL, Liebig MA (eds) Recent Trends in Soil Science and Agronomy Research in the Northern Great Plains of North America. Research Signpost, Trivandrum, Kerala, India, p 427

Gan Y, Liang C, Wang X, and McConkey B. 2011. Lowering carbon footprint of durum wheat by diversifying cropping systems. Field Crop Res 122:199-206

Ghosh, A., Bhattacharyya, R., Meena, M.C., Dwivedi, B.S., Geeta Singh, Agnihotri, R., and Sharma, C. 2018. Long-term fertilization effects on soil organic carbon sequestration in an Inceptisol. Soil Tillage Res. 177: 134-144.

Gregorich EG, Rochette P, Vanden Bygaart AJ, and Angers DA. 2005. Greenhouse gas contributions of agricultural soils and potential mitigation practices in Eastern Canada. Soil Tillage Res 83:5372.

Janzen HH, Angers DA, and Boehm M. 2006. A proposed approach to estimate and reduce net greenhouse gas emissions from whole farms. Can J Soil Sci 86:401-418.

Jat ML, Gathala MK, Saharawat YS, Tetarwal JP, Gupta R., and Yadvinder-Singh. 2013. Double no-till and permanent raised beds in maize-wheat rotation of north-western Indo-Gangetic plains of India: effects on crop yields, water productivity, profitability and soil physical properties. Field Crops Res., 149: 291-299.

Jat, S.L., Parihar, C.M., Singh, A.K., Kumar, B., Choudhary,M., Nayak, H.S., Parihar, M.D., Parihar, N., and Meena, B.R. 2019. Energy auditing and carbon footprint under long-term conservation agriculture-based intensive maize systems with diverse inorganic nitrogen management options. Sci Total Environ. 664:659-668

Lal, R. 2015. Sequestering carbon and increasing productivity by conservation agriculture. J. Soil Water Conserv. 70 (3): $55 \mathrm{~A}-62 \mathrm{~A}$.

Liu, C., Cutforth, H., Chai, Q., and Gan, Y. 2016. Farming tactics to reduce the carbon footprint of crop cultivation in semiarid areas. A review, Agron. Sustain. Dev. 36: 69-76.

Liu, Qi., Benjuan Liu, B., Per Ambus, Yanhui Zhang,Y., Veronika Hansen, V., et al., 2016. Carbon footprint of rice production under bio-char amendment a case study in a Chinese rice cropping system. GCB Bioenergy, 8: 148-159.

Lu, X., and Liao, Y. 2016. Effect of tillage practices on net carbon flux and economic parameters from farmland on the Loess Plateau in China. J. Clean. Prod. https://doi.org/ 10.1016/ j.jclepro. 09.044.

Meena, R.S., Kumar, V., Yadav, G.S., and Mitran, T. 2018. Response and interaction of Bradyrhizobium japonicum and Arbuscular mycorrhizal fungi in the soybean rhizosphere: a review. Plant Growth Regul. 84: 207223.

Mosier, A. R., Duxbury, J. M., Freney, J. R., Heinemeyer, O., Minami, K., and Johnson, D. E. 1998. Mitigating agricultural emissions of methane. Clim. Change. 40: 39-80.

Mukherjee, D. 2010. Productivity profitability and apparent nutrient balance under different crop sequence in mid hill condition. Indian J. Agric. Sci. 80 (5):420-422.

Naresh, R.K., Tyagi, S., Mahajan, N.C., Lali Jat, Richa Tiwari, Kumar, M., and Tomar, S.S. 2018. Does a different 
tillage system after input of rice and wheat residues affect carbon dynamics through changes of allocation of soil organic matter within aggregate fractions? A review, J. Pharm Phytochem 7 (3): 1429-1447

Oenema, O., Wrage, N., Velthof, G. L., van Groenigen, J. W., Dolfing, J., and Kuikman, P. J. 2005. Trends in global nitrous oxide emissions from animal production systems. Nutr. Cycling Agroecosyst. 72: 51-65.

Parihar CM, Jat SL, Singh AK, Kumar B, Singh Yadvinder, Pradhan $\mathrm{S}$, et al., 2016. Conservation agriculture in irrigated intensive maize-based systems of northwestern India: effects on crop yields, water productivity and economic profitability. Field Crops Res., 193:104116.

Parihar, C.M., Jat, S.L., Singh, A.K., Majumdar, K., Jat, M.L., Saharawat, Y.S., Pradhan, S., and Kuri, B.R. 2017a. Bio-energy, water-use efficiency and economics of maize-wheat-mungbean system under precision-conservation agriculture in semi-arid agro-ecosystem. Energy 119:245-256.

Parihar, C.M., Jat, S.L., Singh, A.K., Kumar, B., Rathore, N.S., Jat, M.L., Saharawat, Y.S., and Kuri, B.R. 2018. Energy auditing of long-term conservation agriculture based irrigated intensive maize systems in semi-arid tropics of India. Energy 142: 289-302.

Petersen, S.O., Regina, K., Pöllinger, A., Rigler, E., Valli, L., Yamulki, S., Esala, M., Fabbri, C., Syväsalo, E., and Vinther, F.P. 2006. Nitrous oxide emissions from organic and conventional crop rotations in five European countries. Agr. Ecosyst. Environ. 112: 200-206.

Pratibha, G., Srinivas, I., Rao, K.V., Raju, B.M.K., Thyagaraj, C.R., Korwar, G.R., Venkateswarlu, B., Shanker, A.K.,
Choudhary, D.K., Srinivasrao, K., and Srinivasarao, Ch. 2015. Impact of conservation agriculture practices on energy use efficiency and global warming potential in rainfed pigeonpeacastor systems. Eur. J. Agron. 66: 30-40.

Rajesh,U.Modi., Ali, M., Parmar, R.P., and Namdev, S.K. 2018. Energy Audit Application for Rice-Wheat Cropping System. Orient. J. Comp. Sci. \& Technol., 11(4): 209-218.

Ramchandra T.V., and Nagarathna A.V.2001. Energetics in paddy cultivation in Uttara Kannada district. Energ Convers Manage. 42:131-155

Rautaray, S.K., Mishra, A., and Verma, O.P. 2017. Energy efficiency, productivity and profitability of rice (Oryza sativa L.) based cropping systems for selected conservation practices, Arch Agron Soil Sci, 63(14): 1993-2006.

Robertson, G.P., Paul, E.A.,and Harwood, R.R. 2000. Greenhouse gases in intensive agriculture: Contributions of individual gases to the radiative forcing of the atmosphere. Sci. 289: 1922-1925.

Saikia H, Halim RA, and Bhowmic BC. 2004. Pattern of energy use in high yielding sali rice varieties in Assam, north-east India. Int Rice Res Notes. 29:68-69.

Sanjay-Kumar, V.V., Vageesh, T.S., Abhiram, G.J., and Shilpashree, Y. 2015. Effect of compost enriched with NPK fertilizers and neem oil coated urea on productivity and nutrient use efficiency in maize. Karnataka J. Agric. Sci. 28: 185-188.

Singh, K.P., Prakash, V., Srinivas, K., and Srivastva, A.K. 2008. Effect of tillage management on energy-use efficiency and economics of soybean (Glycine max) based cropping systems under the rain-fed conditions in North-West Himalayan region. Soil Tillage Res. 100: 78-82.

Smith, P. 2004. Carbon sequestration in 
croplands: the potential in Europe and the global context. Eur. J. Agron. 20: 229-236.

Soni, P., Taewichit, C., and Salokhe, V.M. 2013. Energy consumption and $\mathrm{CO}_{2}$ emissions in rain-fed agricultural production systems of Northeast Thailand. Agric. Syst.116: 25-36.

Soni, P., Sinha, R., and Perret, S.R. 2018. Energy use and efficiency in selected rice-base cropping systems of the Middle-Indo Gangetic Plains in India. Energy Rep., 4: 554-564.

Stockmann, U., Adams, M. A., Crawford, J. W., Field, D. J., Henakaarchchi, N., Jenkins, M., et al., 2013. The knowns, known unknowns and unknowns of sequestration of soil organic carbon. Agric. Ecosyst. Environ. 164: 80-99.

Tripathi, R., Nayak, A.K., Bhattacharyya, P., Shukla, A.K., Shahid, M., Raja, R., Panda, B.B., Mohanty, S., Kumar, A., and Thilagam, V.K. 2014. Soil aggregation and distribution of carbon and nitrogen in different fractions after 41years long-term fertilizer experiment in tropical rice-rice system. Geoderma 213: 280-286.

Yadav, G.S., Das, A., Lal, R., Babu, S., Meena, R.S., Saha, P., Singh, R., and Datta, M. 2018. Energy budget and carbon footprint in a no-till and mulch based rice-mustard cropping system. J Cleaner Prod. 191:144-157

Yadav, G.S., Lal, R., Meena, R.S., Datta, M., Babu, S., Das, A., Layek, J., and Saha, P. 2017. Energy budgeting for designing sustainable and environmentally clean/safer cropping systems for rain-fed rice fallow lands in India. J. Clean. Prod. 158: 29-37.

Zhang, D., and Zhang, W. F. 2016. Low carbon agriculture and a review of calculation methods for crop production carbon footprint accounting. Res. Sci. 38: 1395-1405.

Zhang, D., Shen, J., Zhang, F., Li, Yu., and Zhang, W. 2017. Carbon footprint of grain production in China. Sci Rep.7: 4126 DOI:10.1038/s41598-017-04182-x

\section{How to cite this article:}

Sharath Chandra, M., R. K. Naresh, Vivek, Pradeep Kumar Singh, Jana Harish, Pebbeti Chandana and Shivashankar, K. 2020. Energy Auditing and Carbon Footprint with Diverse Organic and Inorganic Fertilizer Management Options in Cereal based Cropping Systems under Conservation Agriculture: A Review. Int.J.Curr.Microbiol.App.Sci. 9(10): 2062-2081. doi: https://doi.org/10.20546/ijcmas.2020.910.252 